\title{
ORIGINAL ARTICLE \\ Is boiled food spice curcumin still biologically active? An experimental exploration
}

\author{
Liang Shen ${ }^{1,2, \dagger}$, Hui-Hui Jiang ${ }^{2, \dagger}$ and Hong-Fang ji,2* \\ Institute of Biomedical Research, Shandong University of Technology, Zibo, China; ${ }^{2}$ Shandong Provincial Research \\ Center for Bioinformatic Engineering and Technique, Shandong University of Technology, Zibo, China
}

\section{Abstract}

Background: As the major active component of turmeric (Curcuma longa), curcumin is widely used as a spice and food coloring agent, and also possesses multiple biological activities and therapeutic potential for neurodegenerative diseases. To answer the paradox between curcumin's biological activities and poor systemic bioavailability, we proposed that degradation products of curcumin may make important contributions to its biological activities, which needs to be verified. In addition, curcumin is usually heated or boiled used as a spice, it is necessary to explore whether boiled curcumin, which degrades readily, is still biologically active.

Methods: Thus, in the present study we investigated the protective effects of curcumin and boiled curcumin mixture on $\mathrm{H}_{2} \mathrm{O}_{2}$-induced oxidative damage in PC12 cells, a widely used model for neurons.

Results: Results showed that in spite of high degradation rates, boiled curcumin mixture still possessed similar protective activities like parent curcumin, and could effectively rescue PC12 cells against $\mathrm{H}_{2} \mathrm{O}_{2}$-induced damage, via decreasing production of reactive oxygen species and malondialdehyde, reducing caspase-3 and caspase-9 activities. Moreover, curcumin's degradation products including ferulic acid, vanillin and vanillic acid could also improve PC12 cells survival rate.

Conclusion: Our findings indicated that boiled curcumin mixtures still possessed protective activity for PC12 cells, and supported the contribution of degradation products to biological activities of curcumin.

Keywords: curcumin; degradation; oxidative damage; apoptosis; PC12 cells

Received: I3 April 20 I8; Revised: 22 May 20 8; Accepted: 29 May 20 I8; Published: 20 June 2018

\section{Introduction}

Curcumin (1,7-bis[4-hydroxy-3-methoxyphenyl]-1,6-heptadiene-3,5-dione) is a natural polyphenolic compound isolated from the spice turmeric (Curcuma longa). It is not only widely used as a food coloring pigment and as a preservative but also has been used as an herbal medicine in many Asian countries for thousands of years $(1,2)$. Accumulating evidence has indicated that curcumin displays a broad spectrum of biological and pharmacological activities, including antioxidant, antiproliferative, anticarcinogenic, anti-inflammatory, antibacterial, and antiviral activities (3-9). Curcumin has been suggested to be a promising natural agent for neurodegenerative diseases such as Alzheimer's disease (AD) and Parkinson's disease (PD) (10-13).

Although curcumin exhibits various biological activities, curcumin possesses poor systemic bioavailability, which makes its pharmacology elusive. In view of the low stability of curcumin we previously proposed that the degradation products of curcumin may make important contributions to its biological activities, which should be further verified (14-16). In addition, when curcumin is used as a spice (such as in curry) it is often heated or boiled, and the heat-treated curcumin is largely degraded. This raises an interesting question, whether boiled curcumin still possesses biological activities. Therefore, we attempted to provide clues for the above questions through investigating the neuroprotective activities of curcumin, a boiled curcumin mixture, and its degradation products. As oxidative damage to neurons is widely accepted to play an important role in the pathogenesis of neurodegenerative diseases, $\mathrm{H}_{2} \mathrm{O}_{2}$-induced oxidative damage in rat pheochromocytoma (PC12) cells, a widely used model for neurons, was employed to evaluate the protective effect of parent curcumin, boiled curcumin mixture, and its degradation products. The results indicated that boiled curcumin could effectively rescue $\mathrm{PC} 12$ cells against $\mathrm{H}_{2} \mathrm{O}_{2}$-induced

†These authors contributed equally to this work. 
death through decreasing the production of reactive oxygen species (ROS) and malondialdehyde (MDA), reducing caspase- 3 and caspase- 9 activities, which helped elucidate the pharmacology of curcumin.

\section{Results}

\section{Cell viability}

Cell viability of PC12 cells treated with parent curcumin, a boiled curcumin mixture, and three degradation products of curcumin was investigated. First, cytotoxic doses of $\mathrm{H}_{2} \mathrm{O}_{2}$, curcumin, boiled curcumin mixture Cur-B1, boiled curcumin mixture Cur-B2, ferulic acid, vanillin, and vanillic acid were screened. The results indicated that $\mathrm{PC} 12$ cell viability was significantly inhibited in the range of $0-1000 \mu \mathrm{M} \mathrm{H}_{2} \mathrm{O}_{2}$ alone for $24 \mathrm{~h}$ incubation and the $\mathrm{IC}_{50}$ value was $499.92 \pm 90.83 \mu \mathrm{M}$ (Fig. 1a). Thus, $500 \mu \mathrm{M} \mathrm{H}_{2} \mathrm{O}_{2}$ was regarded as an oxidative damage model in vitro for the subsequent experiments. The results also showed that exposing PC12 cells to parent curcumin, Cur-B1, Cur-B2, ferulic acid, vanillic acid, and vanillin for $24 \mathrm{~h}$ alone did not reduce cell viability compared with the $0.2 \%$ dimethyl sulfoxide (DMSO)-treated control group (Fig. 1b and c).

Our results indicated that pretreatment of $\mathrm{PC} 12$ cells with parent curcumin, Cur-B1, and Cur-B2 could reverse $\mathrm{H}_{2} \mathrm{O}_{2}$-induced cytotoxicity, respectively. As shown
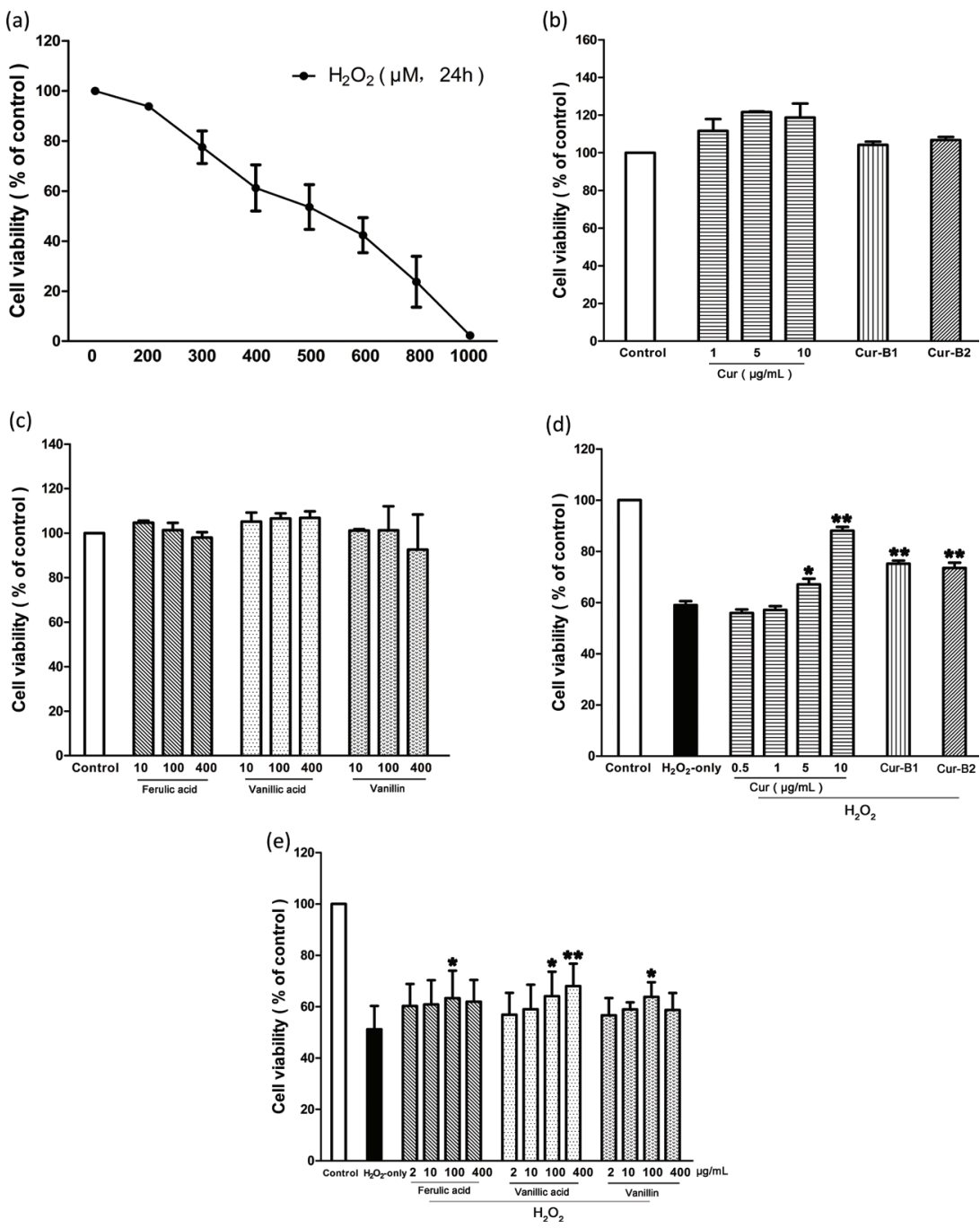

Fig. 1. Cell viability detected by MTT assay. PC12 cells were treated with curcumin $(0.5-10 \mu \mathrm{g} / \mathrm{mL})$, boiled curcumin mixture Cur-B1 $(360 \mu \mathrm{g} / \mathrm{mL})$, boiled curcumin mixture Cur-B2 $(360 \mu \mathrm{g} / \mathrm{mL})$, ferulic acid $(2-400 \mu \mathrm{g} / \mathrm{mL})$, vanillic acid $(2-400 \mu \mathrm{g} / \mathrm{mL})$ and vanillin $(2-400 \mu \mathrm{g} / \mathrm{mL})$ for $0.5 \mathrm{~h}$ prior to exposure to $500 \mu \mathrm{M} \mathrm{H} \mathrm{H}_{2}$. The cytotoxic doses of $\mathrm{H}_{2} \mathrm{O}_{2}$ (a), curcumin, Cur-B1, Cur-B2 (b), and the selected degradation products of curcumin (c) were determined. The protective effect of curcumin, Cur-B1, and Cur-B2 (d) and the selected degradation products of curcumin (e) on $\mathrm{H}_{2} \mathrm{O}_{2}$ induced cytotoxicity in PC12 cells. Data were displayed as mean $\pm \mathrm{SD}$ value from three separate experiments. Bars with different features manifested statistical difference at $p<0.05$. ${ }^{*} p<0.05$, different from $\mathrm{H}_{2} \mathrm{O}_{2}$-only group; $* * p<0.01$, significantly different from $\mathrm{H}_{2} \mathrm{O}_{2}$-only group. 
in Fig. 1d, when PC12 cells were pretreated with parent curcumin, Cur-B1, and Cur-B2, the cell survival rates significantly increased from $59.01 \pm 2.69 \%\left(\mathrm{H}_{2} \mathrm{O}_{2}\right.$ only $)$ to $88.08 \pm 2.58 \%, 75.18 \pm 2.11 \%$, and $73.56 \pm 3.47 \%$, respectively. Moreover, with pretreatment of $\mathrm{PC} 12$ cells with ferulic acid, vanillic acid, and vanillin, the PC12 cell survival rates significantly increased from $51.25 \pm$ $9.07 \%\left(\mathrm{H}_{2} \mathrm{O}_{2}\right.$ only) to $63.33 \pm 10.69 \%, 68.06 \pm 8.70 \%$, and $63.86 \pm 5.66 \%$, respectively (Fig. 1e).

\section{High-performance liquid chromatography with ultraviolet detection (HPLC/UV) analysis of boiled curcumin mixture}

HPLC analysis was performed to estimate the residual content of parent curcumin in boiled curcumin mixture Cur-B1 and boiled curcumin mixture Cur-B2 to illuminate the role of degradation products in the protective effects against $\mathrm{H}_{2} \mathrm{O}_{2}$-induced oxidative damage in $\mathrm{PC} 12$ cells. The results indicated that the residual concentrations of curcumin in Cur-B1 and Cur-B2 were $0.66 \pm$ $0.04 \mu \mathrm{g} / \mathrm{mL}$ and $0.25 \pm 0.03 \mu \mathrm{g} / \mathrm{mL}$, respectively (Fig. 2a). However, as suggested by the cell viability assay results, $1 \mu \mathrm{g} / \mathrm{mL}$ parent curcumin alone could not protect PC12 cells against $\mathrm{H}_{2} \mathrm{O}_{2}$-induced death. Thus, the degradation products made important contributions to the observed protective effects of Cur-B1 and Cur-B2. In addition, the biologically active degradation products, including vanillic acid, ferulic acid, and vanillin, were identified in CurB1 and Cur-B2 (Fig. 2b and c), which was consistent with previous studies $(17,18)$.

\section{Cell morphology and apoptosis}

As shown in Fig. 3a, PC12 cells in the $\mathrm{H}_{2} \mathrm{O}_{2}$-only group flocked together and exhibited typical apoptosis characteristics. However, when PC12 cells were pretreated with parent curcumin, boiled curcumin mixture Cur-B1, and boiled curcumin mixture Cur-B2, a majority of PC12 cells displayed normal cell morphology in each case. The protective effects of boiled curcumin mixture Cur-B1 and boiled curcumin mixture Cur-B2 were similar to those of parent curcumin.

Annexin V-fluorescein isothiocyanate (FITC)/propidium iodide (PI) double staining by flow cytometry was performed to estimate the apoptosis rate of PC12 cells. As shown in Fig. 3b, the apoptosis proportion of control group was $10.00 \pm 1.76 \%$, and it rose to $27.95 \pm 6.71 \%$ after exposure to $\mathrm{H}_{2} \mathrm{O}_{2}$ alone for $12 \mathrm{~h}$. However, this phenomenon could be reversed by pretreatment of curcumin, Cur-B1, or Cur-B2, in which case the apoptosis proportions decreased to $12.64 \pm 2.18 \%, 14.44 \pm 1.32 \%$, and $13.52 \pm 1.55 \%$, respectively. The results suggested that curcumin, Cur-B1, and Cur-B2 could protect PC12 cells against $\mathrm{H}_{2} \mathrm{O}_{2}$-induced apoptosis.

\section{Intracellular ROS levels}

The inhibitory effects of parent curcumin, boiled curcumin mixture Cur-B1, and boiled curcumin mixture Cur-B2 on $\mathrm{H}_{2} \mathrm{O}_{2}$-induced enhancement of intracellular ROS in PC12 cells were estimated by 2',7'-dichlorofluorescin diacetate (DCFH-DA) probe. As shown
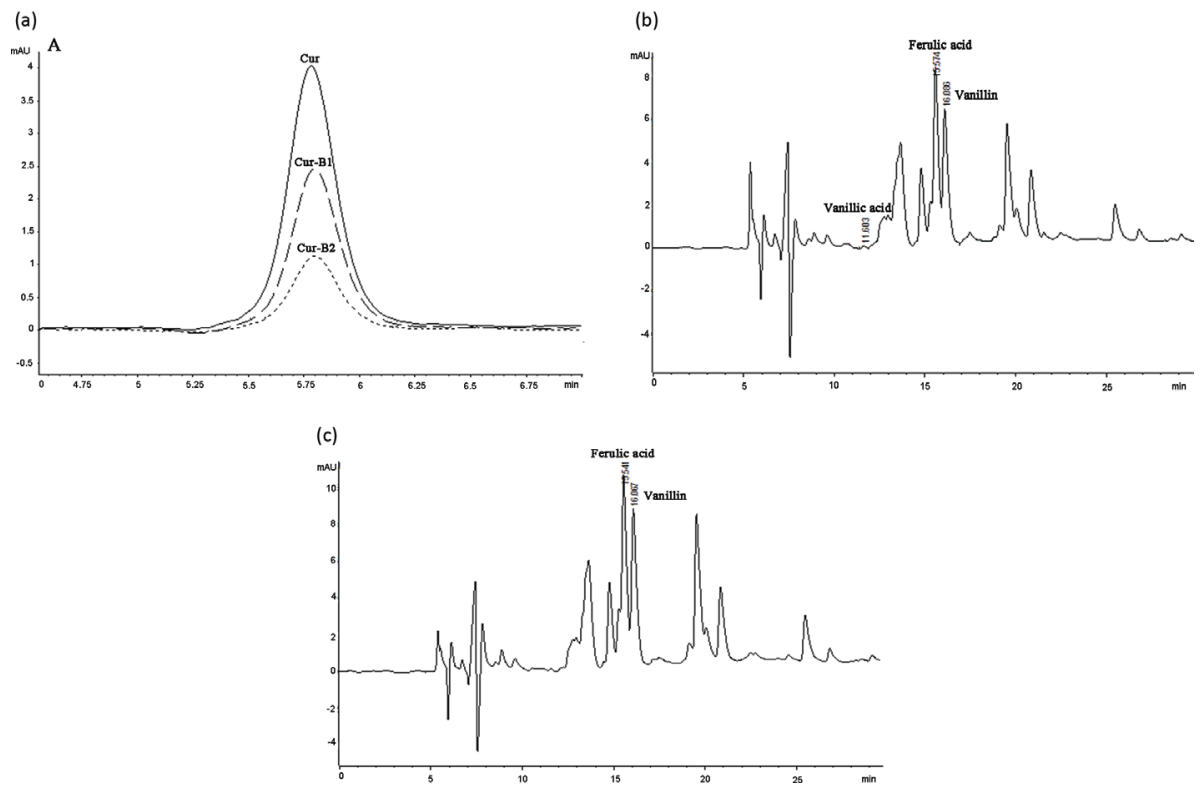

Fig. 2. Chromatogram of standard curcumin, boiled curcumin mixture Cur-B1, and boiled curcumin mixture Cur-B2. The selected degradation products of curcumin (ferulic acid, vanillic acid, and vanillin) were identified by HPLC/UV. Overlapping picture of $1 \mu \mathrm{g} / \mathrm{mL}$ standard curcumin, $360 \mu \mathrm{g} / \mathrm{mL}$ Cur-B1, and $360 \mu \mathrm{g} / \mathrm{mL}$ Cur-B2 at $430 \mathrm{~nm}$ (a); $360 \mu \mathrm{g} / \mathrm{mL} \mathrm{Cur-B1} \mathrm{at} 280 \mathrm{~nm}$ (b); $360 \mu \mathrm{g} / \mathrm{mL}$ Cur-B2 at $280 \mathrm{~nm}$ (c). 
(a)
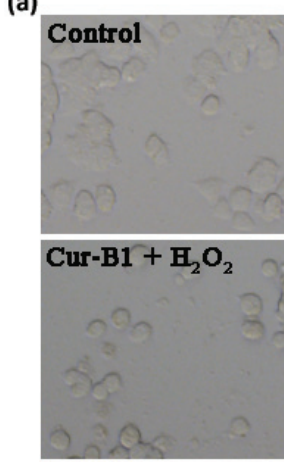

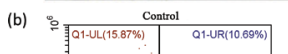
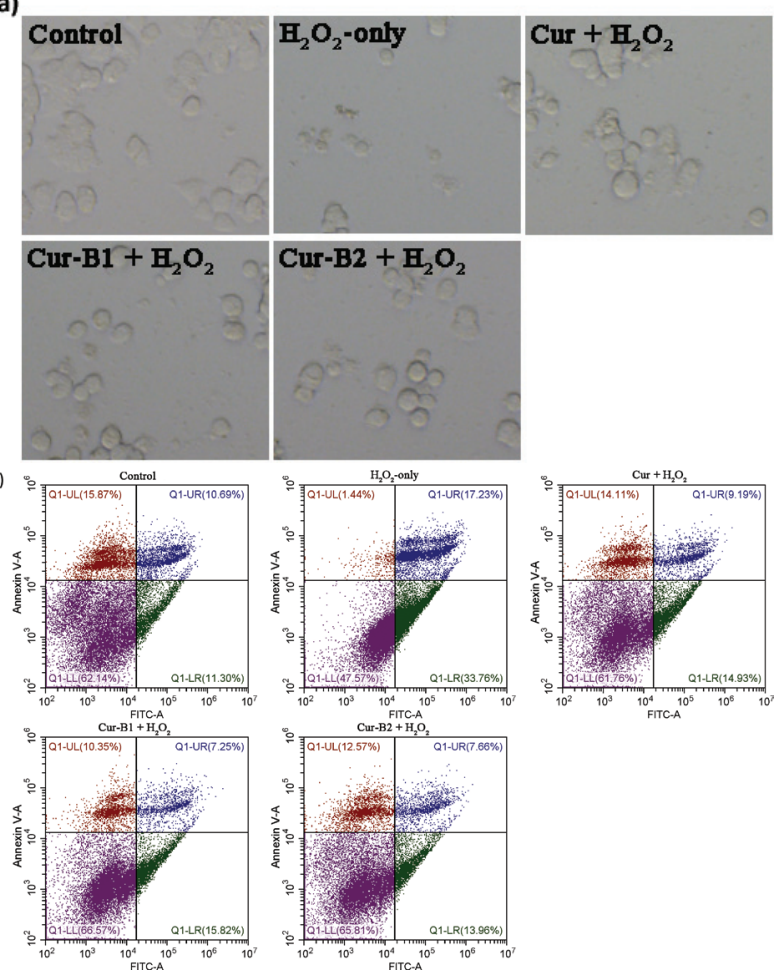

Fig. 3. Inhibitory effects of curcumin, boiled curcumin mixture Cur-B1, and boiled curcumin mixture Cur-B2 on $\mathrm{H}_{2} \mathrm{O}_{2}$ induced PC12 cell apoptosis. PC12 cells were treated with $10 \mu \mathrm{g} / \mathrm{mL}$ curcumin, $360 \mu \mathrm{g} / \mathrm{mL}$ Cur-B1, and $360 \mu \mathrm{g} / \mathrm{mL}$ Cur-B2 for $0.5 \mathrm{~h}$ prior to exposure to $500 \mu \mathrm{M} \mathrm{H}_{2} \mathrm{O}_{2}$. Then, $\mathrm{PC} 12$ cells were observed by a phase contrast microscope $(\times 200)$ (a). PC12 cells were stained with a double dye of annexin V-FITC/PI after treatment with curcumin or boiled curcumin mixture and the apoptosis rates of each group were detected by flow cytometer (b).

in Fig. 4a, the intracellular ROS level of PC12 cells exposed to $\mathrm{H}_{2} \mathrm{O}_{2}$ alone for $4 \mathrm{~h}$ increased markedly to $231.24 \pm 60.00 \%$. However, with pretreatment of PC12 cells with curcumin, Cur-B1, and Cur-B2, the intracellular ROS levels decreased to $141.94 \pm 28.65 \%, 148.98$ $\pm 30.87 \%$, and $144.69 \pm 21.41 \%$, respectively. Thus, Cur-B1 and Cur-B2 could effectively attenuate ROS generation increase caused by $\mathrm{H}_{2} \mathrm{O}_{2}$. The results were in agreement with representative images of DCFH-DA dyeing for PC12 cells as shown in Fig. 4b.

\section{MDA levels}

When PC12 cells were exposed to $\mathrm{H}_{2} \mathrm{O}_{2}$ alone for $12 \mathrm{~h}$ the intracellular MDA generation increased to 159.16 $\pm 14.79 \%$ compared with the control group as shown in Fig. 5. Pretreatment of curcumin, boiled curcumin mixture Cur-B1, and boiled curcumin mixture Cur-B2 could effectively suppress enhancement of MDA levels, and the values decreased to $125.09 \pm 15.42 \%, 116.28 \pm 7.21 \%$, and $122.01 \pm 11.41 \%$, respectively.

\section{Caspase- 3 and caspase- 9 activities}

The effects of boiled curcumin mixture Cur-B1 and boiled curcumin mixture Cur-B2 on caspase-3 and caspase-9 activities in $\mathrm{H}_{2} \mathrm{O}_{2}$-induced $\mathrm{PC} 12$ cells were explored and compared with parent curcumin. As shown in Fig. 6, when PC12 cells were exposed to $\mathrm{H}_{2} \mathrm{O}_{2}$ alone for $12 \mathrm{~h}$, the intracellular caspase-3 activity increased to $142.11 \pm$ $22.73 \%$. However, pretreatment with parent curcumin, Cur-B1, and Cur-B2 could effectively suppress enhancement of caspase-3 activity, and the value decreased to $107.51 \pm 14.31 \%, 114.24 \pm 8.02 \%$, and $102.95 \pm 5.51 \%$, respectively. Similar results were obtained for caspase-9 activity and the corresponding activity decreased from $134.83 \pm 5.68 \%$ for the $\mathrm{H}_{2} \mathrm{O}_{2}$ group to $103.94 \pm 6.81 \%$ for the parent curcumin group, $101.69 \pm 5.33 \%$ for Cur-B1, and $105.12 \pm 9.21 \%$ for Cur-B2.

\section{Discussion}

Curcumin is one of the most intensively studied natural compounds for its wide range of biological and pharmacological activities, as well as its potential therapeutic applications for many diseases. However, curcumin has very poor systemic bioavailability resulting from its very low water solubility, instability, rapid metabolism, and poor absorption as indicated in preclinical and clinical studies (2, 19-23). Many studies demonstrated that the levels of curcumin and its metabolites were rather low in serum and tissue levels even with high doses in vivo (2, 19-23). Thus, how curcumin executes the observed biological effects with the perquisite of poor systemic bioavailability remains elusive. On the basis of the low stability of curcumin, we previously proposed that the degradation products of curcumin could play an important role in executing the biological activities of curcumin (14-16). In addition, curcumin is considered to be the major active component of the curry spice turmeric, which is often heated or boiled during cooking. It is interesting to explore whether the boiled curcumin, while largely degraded, is still biologically active. The present study was designed to investigate the protective effects of curcumin, a boiled curcumin mixture, and its selected degradation products on $\mathrm{H}_{2} \mathrm{O}_{2}$-induced oxidative damage in $\mathrm{PC} 12$ cells. Consistent with previous findings it was found that parent curcumin can protect $\mathrm{PC} 12$ cells from $\mathrm{H}_{2} \mathrm{O}_{2}$-induced damage $(24,25)$. Despite the high degradation rates after boiling, the boiled curcumin mixture still exhibited strong protective activities against $\mathrm{H}_{2} \mathrm{O}_{2}$-induced damage in PC12 cells, and its activity was similar to that of parent curcumin. The observed higher concentrations of boiled curcumin mixture than parent curcumin in exerting the protective effects should arise in part from the large content of phosphate buffer saline (PBS) in the mixture. Thus, the current study suggested that the boiled curcumin mixture was still biologically active in protecting PC12 cells against 
(a)

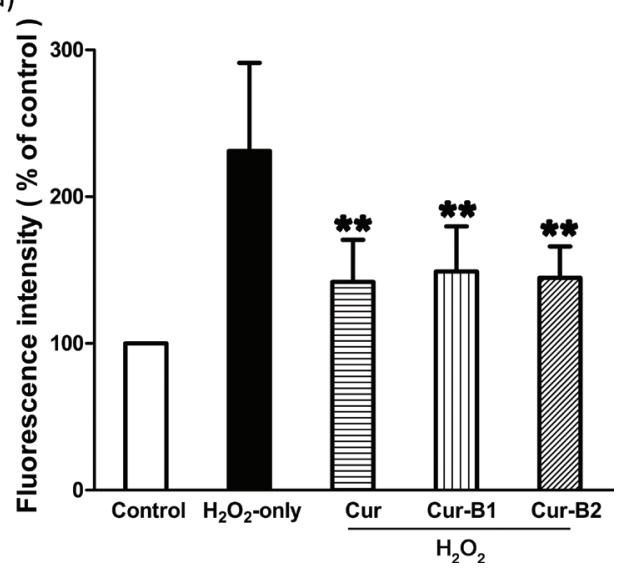

(b)
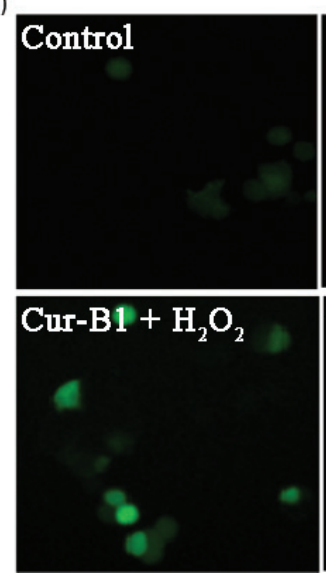

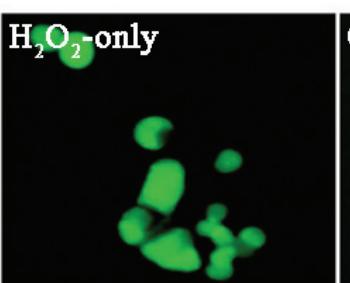

$\mathrm{Cur}+\mathrm{H}_{2} \mathrm{O}_{2}$

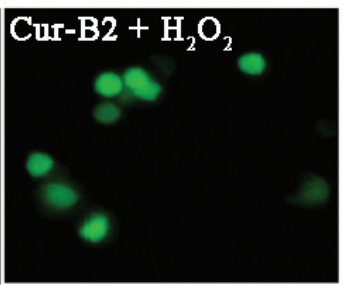

Fig. 4. Inhibitory effects of curcumin, boiled curcumin mixture Cur-B1, and boiled curcumin mixture Cur- $\mathrm{B} 2$ on $\mathrm{H}_{2} \mathrm{O}_{2}$-induced intracellular ROS enhancement in PC12 cells. PC12 cells were treated with $10 \mu \mathrm{g} / \mathrm{mL}$ curcumin, $360 \mu \mathrm{g} / \mathrm{mL}$ Cur-B1, and $360 \mu \mathrm{g} / \mathrm{mL}$ Cur-B2 for $0.5 \mathrm{~h}$ prior to exposure to $500 \mu \mathrm{M} \mathrm{H}_{2} \mathrm{O}_{2}$. DCFH-DA fluorescence intensity analysis was shown as mean $\pm \mathrm{SD}$ values from three separate experiments through a fluorescence microplate reader (a). Bars with different features manifested statistical difference at $p<0.05 .{ }^{*} p<0.05$, different from the $\mathrm{H}_{2} \mathrm{O}_{2}$-only group; ${ }^{* *} p<0.01$, significantly different from the $\mathrm{H}_{2} \mathrm{O}_{2}$-only group. Representative images of DCFH-DA staining in PC12 cells were observed by fluorescent microscopy (b).

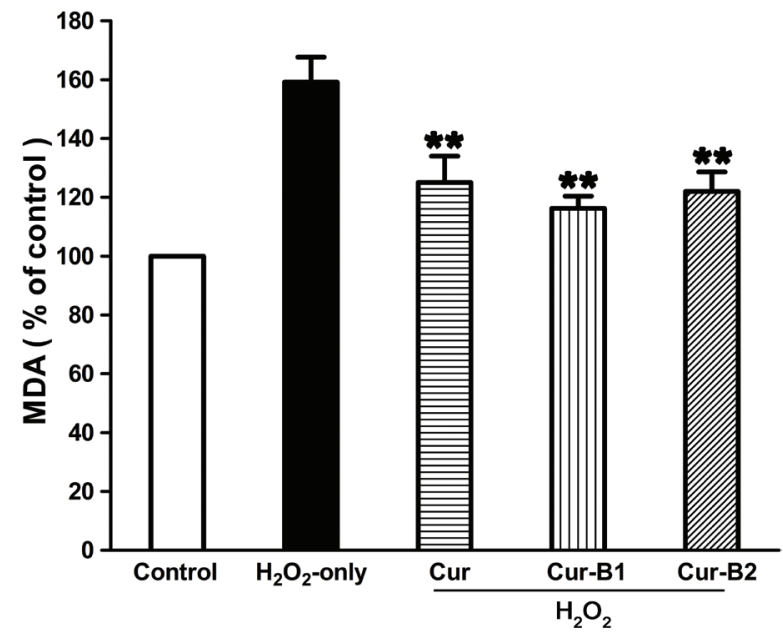

Fig. 5. Suppressing effects of curcumin, boiled curcumin mixture Cur-B1, and boiled curcumin mixture Cur-B2 on $\mathrm{H}_{2} \mathrm{O}_{2}$-induced enhancement of MDA level in $\mathrm{PC} 12$ cells. PC12 cells were treated with $10 \mu \mathrm{g} / \mathrm{mL}$ curcumin, $360 \mu \mathrm{g} / \mathrm{mL}$ Cur-B1, and $360 \mu \mathrm{g} / \mathrm{mL}$ Cur-B2 for $0.5 \mathrm{~h}$ prior to exposure to $500 \mu \mathrm{M} \mathrm{H}_{2} \mathrm{O}_{2}$. Data were manifested as mean $\pm \mathrm{SD}$ values from three independent experiments. Bars with different characteristics show statistical difference at $p<0.05 .{ }^{*} p<0.05$, different from $\mathrm{H}_{2} \mathrm{O}_{2}$-only group; ${ }^{* *} p<0.01$, significantly different from $\mathrm{H}_{2} \mathrm{O}_{2}$-only group.

oxidative damage and supported the theory that the degradation products of curcumin make important contributions to the biological activities of curcumin.

The observed biological activities of the boiled curcumin mixture may result from the similar biological activities of curcumin's degradation products. It was demonstrated that curcumin degraded readily under high temperature or $\mathrm{pH}$, and despite the varying degradation products used, most of them possessed the phenolic hydroxyl group (26-28). Thus, many identified degradation products, such as ferulic acid, vanillin, and vanillic acid, possess antioxidant potentials (26-28). In agreement with our present findings, many studies reported that ferulic acid and vanillin exhibited protective effects on oxidative damage in PC12 cells (29-31). Moreover, we previously reported that curcumin's degradation product mixture also possessed biological activities for AD-associated therapeutic targets, including inhibiting amyloid- $\beta$ peptide fibril formation, acetylcholinesterase, and $\beta$-amyloid precursor cleavage enzymes (32). In combination with the present findings of the protective effects of the boiled curcumin mixture on PC12 cells, we proposed that boiled curcumin mixture also possessed multiple biological activities.

\section{Conclusion}

In summary, our study suggested that curcumin was still active after boiling to protect $\mathrm{PC} 12$ cells from $\mathrm{H}_{2} \mathrm{O}_{2}$ induced damage, via decreasing the production of ROS and MDA and inhibiting the activities of caspase- 3 and caspase-9. The findings further supported our hypothesis that the degradation products played an important role in executing the biological activities of curcumin and also provided a plausible interpretation of the paradox between the widely recognized biological activities and in vivo poor bioavailability of curcumin. 

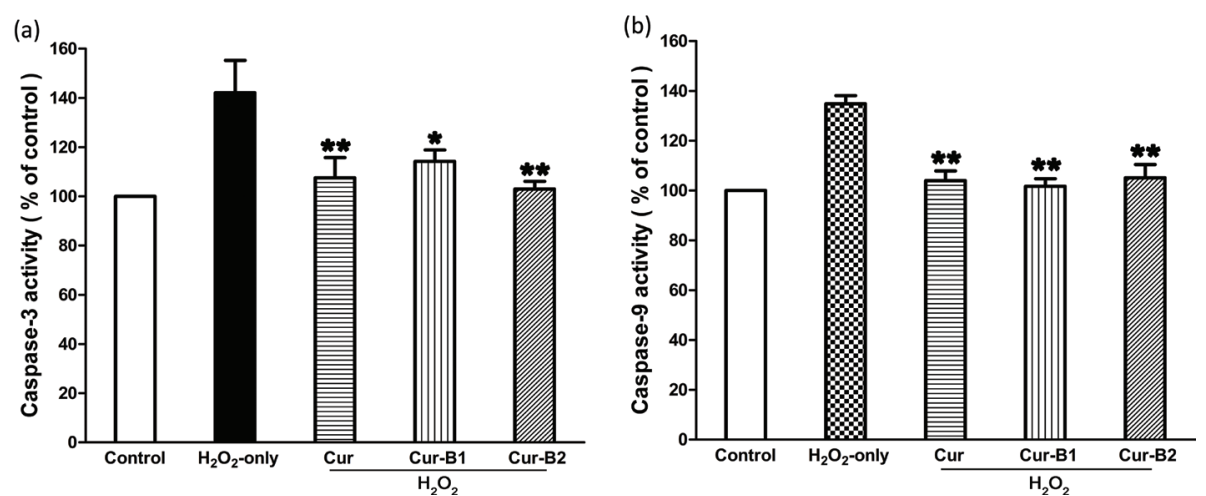

Fig. 6. Suppressing effects of curcumin, boiled curcumin mixture Cur-B1 and boiled curcumin mixture $\mathrm{Cur}-\mathrm{B} 2$ on $\mathrm{H}_{2} \mathrm{O}_{2}$-induced caspase-3 (a) and caspase-9 (b) activation in PC12 cells.

\section{Materials and methods}

\section{Materials and reagents}

Poly-D-lysine hydrobromide, ferulic acid (99\%), vanillin (99\%), vanillic acid (97\%), 3-(4,5-dimethylthialzal-z-yl)-2,5-diphenylterazolium (MTT), DCFH-DA probes, and Nutrient Mixture F-12 Ham were purchased from the Sigma-Aldrich Shanghai Trading Co. (Shanghai, China). Curcumin (98\%) was obtained from the Aladdin Industrial Corporation (Shanghai, China). Fetal bovine serum (FBS) was bought from (Gibco BRL, Grand Island, NY, USA). Horse serum was bought from Solarbio Biological Technology Co., Ltd. (Beijing, China). Hydrogen peroxide $\left(\mathrm{H}_{2} \mathrm{O}_{2}\right)$ was obtained from Shuangshuang Chemical Co., Ltd. (Yantai, China). An annexin V-FITC/PI apoptosis detection kit was obtained from Bibo Biological Technology Co., Ltd. (Nanjing, China). A Bradford protein assay kit, caspase-3 activity assay kit, caspase- 9 activity assay kit, and cell MDA assay kit were obtained from Nanjing Jiancheng Bioengineering Institute (Nanjing, China). All other reagents used were of analytical grade.

\section{Preparation of boiled curcumin mixture}

Our preliminary experiments and previous studies demonstrated that curcumin degraded readily when it was incubated in physiological PBS at high temperature or $\mathrm{pH}$ (data not shown) $(17,18)$. After a systematic exploration we chose the degradation conditions (PBS, pH 7.2 and 8.0, heated to $100^{\circ} \mathrm{C}$ for $2 \mathrm{~h}$ ) to obtain two boiled curcumin mixtures. Aliquots of $1.0 \mathrm{mg}$ curcumin powder were added to $1.0 \mathrm{~mL}$ of $0.01 \mathrm{M}$ PBS, pH 7.2 and 8.0 , and the samples were heated to $100^{\circ} \mathrm{C}$. After boiling for $2 \mathrm{~h}$, the supernatant of the mixture was frozen at low temperature $\left(-45^{\circ} \mathrm{C}\right)$ by LGJ-10B Vacuum Freeze Dryer (Four-Ring Science Instrument Plant Beijing, Beijing, China) to get the boiled curcumin mixture powders called Cur-B1 (PBS, pH 7.2, heated to $100^{\circ} \mathrm{C}$ for $2 \mathrm{~h}$ ) and Cur-B2 (PBS, pH 8.0, heated to $100^{\circ} \mathrm{C}$ for $2 \mathrm{~h}$ ) and was redissolved in DMSO.

\section{Cell culture}

A rat pheochromocytoma PC12 cell line was obtained from the Type Culture Collection of the Chinese Academy of Sciences (Shanghai, China). PC12 cells were grown in Nutrient Mixture F-12 Ham media containing 10\% horse serum and $5 \% \mathrm{FBS}$ at $37^{\circ} \mathrm{C}$ under an atmosphere of $5 \%$ $\mathrm{CO}_{2}$. To evaluate the protective effect of boiled curcumin on $\mathrm{H}_{2} \mathrm{O}_{2}$-induced oxidative damage, $\mathrm{PC} 12$ cells were pre-incubated with curcumin, boiled curcumin mixture Cur-B1, or boiled curcumin mixture Cur-B2 before adding $\mathrm{H}_{2} \mathrm{O}_{2}$.

\section{Cell viability}

MTT assay was used to detect PC12 cell viability. Briefly, PC12 cells were seeded at a density of $10^{4}$ cells/well in 96-well tissue culture plates with Poly-D-lysine hydrobromide. After attachment PC12 cells were pre-incubated with different concentrations of curcumin $(0.5-10 \mu \mathrm{g} / \mathrm{mL})$, Cur-B1 $(360 \mu \mathrm{g} / \mathrm{mL})$, and Cur-B2 $(360 \mu \mathrm{g} / \mathrm{mL})$, ferulic acid $(2-400 \mu \mathrm{g} / \mathrm{mL})$, vanillin $(2-400 \mu \mathrm{g} / \mathrm{mL})$, or vanillic acid $(2-400 \mu \mathrm{g} / \mathrm{mL})$ for $0.5 \mathrm{~h}$ and treated without or with $\mathrm{H}_{2} \mathrm{O}_{2}$ $(500 \mu \mathrm{M})$ for an additional $24 \mathrm{~h}$. Then, PC12 cells were incubated with $0.5 \mathrm{mg} / \mathrm{mL}$ MTT for $4 \mathrm{~h}$, and DMSO was used to dissolve the blue formazan product. The absorbance reflected cell viability measured at $570 \mathrm{~nm}$ by Multiskan GO (Thermo Fisher Scientific, Vantaa, Finland). Cell viability was shown as a percent of the value in the control groups.

\section{HPLC analysis}

HPLC analysis was carried out on an Agilent 1100 (Santa Clara, CA, USA) HPLC system, which was equipped with an Agilent UV-DAD G1315B detector and an Agilent G1311A quaternary pump. Curcumin was separated by $\mathrm{C} 18$ column (Diamonsil, $5 \mu \mathrm{m}, 4.6 \times$ $250 \mathrm{~mm}$, Dikma, China) monitored with a refillable precolumn $(\mathrm{C} 18,2.0 \times 20 \mathrm{~mm}$, Alltech, Virginia, USA $)$ at $35^{\circ} \mathrm{C}$. We chose $430 \mathrm{~nm}$ as the detection wavelength and the flow rate was $1.0 \mathrm{~mL} / \mathrm{min}$. The residual content of 
curcumin in the boiled curcumin mixtures Cur-B1 and Cur-B2 was based on its calibration standard curves. The HPLC/UV method was used to identify the three active components of the boiled curcumin mixture: ferulic acid, vanillin, and vanillic acid. The HPLC system was the same as described above. To separate the three active components we chose $280 \mathrm{~nm}$ as the detection wavelength and $0.4 \mathrm{~mL} / \mathrm{min}$ as the flow rate, maintaining the temperature at $35^{\circ} \mathrm{C}$.

\section{Cell morphology and apoptosis}

A phase contrast microscope was used to observe the cell morphology. Briefly, PC12 cells were exposed to $10 \mu \mathrm{g} /$ $\mathrm{mL}$ curcumin, $360 \mu \mathrm{g} / \mathrm{mL}$ Cur-B1, or $360 \mu \mathrm{g} / \mathrm{mL}$ Cur-B2 for $0.5 \mathrm{~h}$ and co-incubated with $500 \mu \mathrm{M} \mathrm{H}_{2} \mathrm{O}_{2}$ for another $12 \mathrm{~h}$. The cellular morphology of the PC12 cells was observed and compared by a phase contrast microscope $(\times 200)$. Then, PC12 cells were collected and stained with a combination of annexin V-FITC and PI to detect apoptosis by flow cytometer following the manufacturer's instructions for the annexin V-FITC apoptosis detection kit (Beckman Coulter, USA).

\section{Intracellular ROS assay}

ROS generation was detected by a fluorometric assay based on the intracellular oxidation of DCFH-DA with $485 \mathrm{~nm}$ excitation and $520 \mathrm{~nm}$ emission wavelengths. Curcumin or boiled curcumin mixture treatment of PC12 cells was the same as with the preceding apoptosis assay. Then, PC12 cells were dyed with $10 \mu \mathrm{M}$ DCF$\mathrm{H}$-DA probes for $30 \mathrm{~min}$ in the darkness, mildly bathed four times (employing basal medium without serum), and promptly observed by fluorescent microscopy (Olympus IX73, Tokyo, Japan) or fluorescent Varioskan Flash (Thermo Fisher Scientific Oy). An improved method was referred as detailed in reference to enhance accuracy (33). The intracellular ROS level of control group was regarded as $100 \%$ and the levels of other groups were calculated as a percentage of it.

\section{MDA assay}

The MDA level of PC12 cells was detected by the Bradford protein assay kit and cell MDA assay kit following the manufacturer's instructions. Curcumin or boiled curcumin mixture treatment of $\mathrm{PC} 12$ cells was the same as the previously described apoptosis assay. The MDA levels of the control group were regarded as $100 \%$ and other groups were calculated as a percent of it.

\section{Caspase-3 and caspase-9 activity assay}

The caspase- 3 and caspase- 9 activities were estimated by the Bradford protein assay kit, Caspase- 3 assay kit, and Caspase-9 assay kit. PC12 cells were given the same treatment as in the preceding apoptosis assay; they were then harvested and their caspase- 3 and caspase- 9 activities were estimated following the corresponding manufacturer's instructions. The detection wavelength of the chromophore p-nitroanilide generation was $405 \mathrm{~nm}$ by MultiskanGo (Thermo Fisher Scientific). The caspase levels of the control group were defined as $100 \%$ and the other groups were calculated as a percent of them.

\section{Statistical analysis}

Statistical analysis was operated in this study through SPSS (16.0) software. One-way analysis of variance and Tukey's multiple comparison post-test were used to analyze the differences between groups. All values were described at the lowest from three independent experiments and shown as the mean \pm SD. Differences were expressed as $p<0.05\left(^{*}\right)$ and significant differences were expressed as $p<0.01(* *)$.

\section{Conflict of interest and funding}

The authors declare no potential conflicts of interest. This work was supported by the Shandong Provincial Science Foundation (Grant No. JQ201508 and ZR2018MH010), the Key Research and Development Program of Shandong (2018GSF121001), and the Zibo Key Laboratory for Neurodegenerative Diseases Drug development.

\section{Ethical approval}

This article does not contain any studies with human participants performed by any of the authors.

\section{Informed consent}

Informed consent was obtained from all individual participants included in the study.

\section{References}

1. Singh S. From exotic spice to modern drug? Cell 2007; 130: $765-8$.

2. Aggarwal BB, Sundaram C, Malani N, Ichikawa H. CurcumIn: the Indian solid gold. Adv Exp Med Biol 2007; 595: 1-75.

3. Aggarwal BB, Sung B. Pharmacological basis for the role of curcumin in chronic diseases: an age-old spice with modern targets. Trends Pharmacol Sci 2009; 30: 85-94.

4. Anand P, Thomas SG, Kunnumakkara AB, Sundaram C, Harikumar KB, Sung B, et al. Biological activities of curcumin and its analogues (Congeners) made by man and Mother Nature. Biochem Pharmacol 2008; 76: 1590-611.

5. Heger M, van Golen RF, Broekgaarden M, Michel MC. The molecular basis for the pharmacokinetics and pharmacodynamics of curcumin and its metabolites in relation to cancer. Pharmacol Rev 2013; 66: 222-307.

6. Aggarwal BB, Yuan W, Li S, Gupta SC. Curcumin-free turmeric exhibits anti-inflammatory and anticancer activities: identification of novel components of turmeric. Mol Nutr Food Res 2013; 57: 1529-42. 
7. Aggarwal BB, Kumar A, Bharti AC. Anticancer potential of curcumIn: preclinical and clinical studies. Anticancer Res 2003; 23: 363-98.

8. Vallianou NG, Evangelopoulos A, Schizas N, Kazazis C. Potential anticancer properties and mechanisms of action of curcumin. Anticancer Res 2015; 35: 645-51.

9. Goel A, Jhurani S, Aggarwal BB. Multi-targeted therapy by curcumIn: how spicy is it? Mol Nutr Food Res 2008; 52: 1010-30.

10. Goozee KG, Shah TM, Sohrabi HR, Rainey-Smith SR, Brown $\mathrm{B}$, Verdile $\mathrm{G}$, et al. Examining the potential clinical value of curcumin in the prevention and diagnosis of Alzheimer's disease. Br J Nutr 2016; 115: 449-65.

11. Darvesh AS, Carroll RT, Bishayee A, Novotny NA, Geldenhuys WJ, Van der Schyf CJ. Curcumin and neurodegenerative diseases: a perspective. Expert Opin Investig Drugs 2012; 21: 1123-40.

12. Ji HF, Shen L. The multiple pharmaceutical potential of curcumin in Parkinson's disease. CNS Neurol Disord Drug Targets 2014; 13: 369-73.

13. Yang F, Lim GP, Begum AN, Ubeda OJ, Simmons MR, Ambegaokar SS, et al. Curcumin inhibits formation of amyloid $\beta$ oligomers and fibrils, binds plaques, and reduces amyloid in vivo. J Biol Chem 2005; 280: 5892-901.

14. Shen L, Ji HF. The pharmacology of curcumIn: is it the degradation products? Trends Mol Med 2012; 18: 138-44.

15. Shen L, Ji HF. Contribution of degradation products to the anticancer activity of curcumin. Clin Cancer Res 2009; 15: 7108-9.

16. Ji HF, Shen L. Can improving bioavailability improve the bioactivity of curcumin? Trends Pharmacol Sci 2014; 35: 265-6.

17. Wang YJ, Pan MH, Cheng AL, Lin LI, Ho YS, Hsieh CY, et al. Stability of curcumin in buffer solutions and characterization of its degradation products. J Pharm Biomed Anal 1997; 15: 1867-76.

18. Lin JK, Pan MH, Lin-Shiau SY. Recent studies on the biofunctions and biotransformations of curcumin. Biofactors 2000; 13: $153-8$.

19. Anand P, Kunnumakkara AB, Newman RA, Aggarwal BB. Bioavailability of curcumIn: problems and promises. Mol Pharm 2007; 4: 807-18.

20. Dhillon N, Aggarwal BB, Newman RA, Wolff RA, Kunnumakkara AB, Abbruzzese JL, et al. Phase II trial of curcumin in patients with advanced pancreatic cancer. Clin Cancer Res 2008; 14: 4491-9.

21. Sharma RA, McLelland HR, Hill KA, Ireson CR, Euden SA, Manson MM, et al. Pharmacodynamic and pharmacokinetic study of oral Curcuma extract in patients with colorectal cancer. Clin Cancer Res 2001; 7: 1894-900.

22. Lao CD, Ruffin MT 4th, Normolle D, Heath DD, Murray SI, Bailey JM, et al. Dose escalation of a curcuminoid formulation. BMC Complement Altern Med 2006; 6: 10.
23. Goel A, Kunnumakkara AB, Aggarwal BB. Curcumin as 'Curecumin': from kitchen to clinic. Biochem Pharmacol 2008; 75: 787-809.

24. Siddiqui MA, Kashyap MP, Kumar V, Tripathi VK, Khanna VK, Yadav S, et al. Differential protection of pre-, co- and post-treatment of curcumin against hydrogen peroxide in $\mathrm{PC} 12$ cells. Hum Exp Toxicol 2011; 30: 192-8.

25. Park SY, Kim HS, Cho EK, Kwon BY, Phark S, Hwang KW, et al. Curcumin protected $\mathrm{PC} 12$ cells against beta-amyloid-induced toxicity through the inhibition of oxidative damage and tau hyperphosphorylation. Food Chem Toxicol 2008; 46: 2881-7.

26. Srinivasan M, Sudheer AR, Menon VP. Ferulic acid: therapeutic potential through its antioxidant property. J Clin Biochem Nutr 2007; 40: 92-100.

27. Shen L, Ji HF. Theoretical study on physicochemical properties of curcumin. Spectrochimic Acta A Mol Biomol Spectrosc 2007; 67: 619-23.

28. Makni M, Chtourou Y, Fetoui H, Garoui el M, Boudawara T, Zeghal N. Evaluation of the antioxidant, anti-inflammatory and hepatoprotective properties of vanillin in carbon tetrachloride-treated rats. Eur J Pharmacol 2011; 668: 133-9.

29. Shen Y, Zhang H, Wang L, Qian H, Qi Y, Miao X, et al. Protective effect of ferulic acid against 2,2'-azobis(2-amidinopropane) dihydrochloride-induced oxidative stress in PC12 cells. Cell Mol Biol 2016; 62: 109-16.

30. Yao SW, Wen XX, Huang RQ, He RR, Ou SY, Shen WZ, et al. Protection of feruloylated oligosaccharides from corn bran against oxidative stress in PC 12 cells. J Agric Food Chem 2014; 62: 668-74.

31. Kim HJ, Hwang IK, Won MH. Vanillin, 4-hydroxybenzyl aldehyde and 4-hydroxybenzyl alcohol prevent hippocampal CA1 cell death following global ischemia. Brain Res 2007; 1181: 130-41.

32. Shen L, Liu CC, An CY, Ji HF. How does curcumin work with poor bioavailability? Clues from experimental and theoretical studies. Sci Rep 2016; 6: 20872.

33. Wang G, Gong Y, Burczynski FJ, Hasinoff BB. Cell lysis with dimethyl sulphoxide produces stable homogeneous solutions in the dichlorofluorescein oxidative stress assay. Free Radic Res 2008; 42: 435-41.

\section{*Hong-Fang Ji}

Shandong Provincial Research Center for Bioinformatic

Engineering and Technique

School of Life Sciences

Shandong University of Technology

Zibo 255049, China.

Email:jhf@sdut.edu.cn 